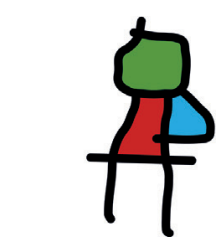

SEICAIP

\section{Allergologia et \\ immunopathologia}

Sociedad Española de Inmunología Clínica,

Alergología y Asma Pediátrica

ORIGINAL ARTICLE

www.all-imm.com

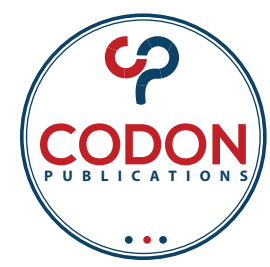

OPEN ACCESS C(1) (1)

\title{
Hospital admission for symptoms exacerbation in 2,075 infants suffering from recurrent asthma-like symptoms: (EISL-3 South America)
}

\author{
Javier Mallol ${ }^{a *}$, Dirceu Soléb, Carolina Aranda ${ }^{\mathrm{b}}$, Eliana C. Toledoc, Viviana Aguirre ${ }^{\mathrm{a}}$, \\ Marilyn Urrutia-Pereira ${ }^{d, e}$, Gabriela A. Szulman ${ }^{f}$, Nelson Rosarios, Herberto Chong, \\ Líllian Sanchez-Lacerdah, Jurg Niederbacher ${ }^{i}$, Catalina Pinchak ${ }^{j}$, \\ Patricia Polles de Oliverak, Erika Arruda-Chávez', Luis García-Marcos ${ }^{\mathrm{m}, \mathrm{n}}$ and \\ the EISL Phase 3 Study Group South America ${ }^{\circ}$
}

\footnotetext{
${ }^{a}$ Department of Pediatric Respiratory Medicine, Hospital El Pino, University of Santiago de Chile (USACH), Santiago, Chile ${ }^{b}$ Division of Allergy, Clinical Immunology and Rheumatology, Department of Pediatrics, Federal University of São Paulo (UNIFESP), São Paulo, Brazil

'Departamento de Pediatria e Cirurgia Pediátrica, Faculdade de Medicina de São José do Rio Preto (FAMERP), São José do Rio Preto, Brazil

${ }^{d}$ Federal University of Pampa, Uruguayana, Rio Grande do Sul, Brazil

ePediatric Asthma Prevention Program (PIPA), Uruguaiana, Brazil

fHospital de Niños "Ricardo Gutiérrez", Buenos Aires, Argentina

${ }^{\circledR}$ Department of Pediatrics, Hospital de Clínicas, Federal University of Paraná (UFPR), Curitiba, Brazil

hDepartment of Pediatrics, Federal University of Mato Grosso, Cuiaba, Brazil

'Escuela de Medicina, Universidad Industrial de Santander, Bucaramanga, Colombia

${ }^{j}$ Clínica Pediátrica “B”. Hospital Pereira Rossell, Facultad Medicina, Universidad de la Republica, Montevideo, Uruguay

kDepartment of Pediatrics, Universidade Federal de São Carlos (UFSCAR), São Carlos, Brazil

'Section of Allergy and Clinical Immunology, British American Hospital, Lima, Peru

mPediatric Respiratory and Allergy Units, "Virgen de la Arrixaca" University Children's Hospital, University of Murcia, Murcia, Spain

"IMIB Research Institute, Murcia, Spain

${ }^{\circ}$ EISL Phase 3 Study Group South America (listed at the end of the manuscript)
}

Received: 5 January 2021; Accepted: 24 May 2021

Available online: 1 July 2021

*Corresponding author: Prof. Javier Mallol, Department of Pediatric Respiratory Medicine, Hospital CRS El Pino, USACH, Ave. Alberto Hurtado 13560, Santiago, Chile. Email address: javier.mallol@usach.cl 


\section{Abstract}

Background: Contrary to what happens in children and adults, the prevalence and the factors related to hospitalisation for asthma/wheezing in infants with recurrent asthma-like symptoms are poorly known.

Methods: This study is part of the International Study of Wheezing in infants Phase 3; 2,079 infants (aged 12-18 months) with recurrent asthma-like symptoms, from 11 South American centres, were studied to determine the prevalence and the associated factors for wheezing exacerbation admission. Descriptive statistics and multivariate logistic regression were employed for analysis.

Results: The prevalence of admission for wheezing was $29.7 \%$ (95\% Cl 27.7-31.6) and was significantly associated to severe wheezing episodes (OR: 3.89; 95\% Cl: 2.93-5.18, $\mathrm{p}<0.001$ ), physician-diagnosed asthma (OR: 1.79; 95\% Cl: 1.33-2.41, $\mathrm{p}<0.0001$ ), use of inhaled corticosteroids (OR: 1.78; 95\% Cl: 1.38-2.29, $\mathrm{p}<0.0001)$, maternal tobacco smoking during pregnancy (OR: 1.69; $95 \% \mathrm{Cl}: 1.19-2.39, \mathrm{p}=0.003)$ and onset of wheezing in the first trimester of life (OR: 1.30; $95 \% \mathrm{Cl}: 1.02-1.66, \mathrm{p}=0.038)$. Breast feeding $\geq 4$ months (OR: $0.72 ; 95 \% \mathrm{Cl}: 0.54-0.96, \mathrm{p}=0.004$ ), maternal high educational level ( $>12$ years) (OR: $0.66 ; 95 \% \mathrm{Cl}: 0.51-0.85, \mathrm{p}=0.001)$ and total monthly household income $\geq$ US\$ 3,000 (OR: $0.34 ; 95 \% \mathrm{Cl}: 0.18-0.67, \mathrm{p}=0.002$ ), were protective factors.

Conclusions: Infants with recurrent asthma-like symptoms have a high rate of admissions. Tobacco smoking in pregnancy, viral respiratory illness in the first trimester of life and severe progression were risks for admissions. Improving medical management to prevent severe exacerbations, prolonging the postnatal period at home longer than 3 months, favouring breastfeeding and avoiding smoking during pregnancy may have a preventive role for admissions in infants with recurrent asthma-like symptoms.

(c) 2021 Codon Publications. Published by Codon Publications.

\section{KEYWORDS}

asthma admissions; recurrent wheeze infants; severe wheezing; wheezing illness; wheezing prevalence; young children

\section{Introduction}

A significant group of infants with recurrent asthma-like symptoms (also called recurrent wheezing, recurrent lower respiratory illness, among others) progress with severe episodes resulting in frequent consultations to Emergency Department (ED) and subsequent admissions. ${ }^{1-4}$ This feature has been highlighted by the International Study of Wheezing in Infants (EISL) from the Spanish Estudio Internacional de Sibilancias en Lactantes and occurs in affluent and nonaffluent localities., ${ }^{1,2}$ This more severe progression can be related to severe comorbidities such as pneumonia ${ }^{5}$ and enhanced use of health facilities and admissions to hospital, particularly in developing countries., ${ }^{1,5-9}$

Hospital admissions for wheezing in early life has been identified as a risk factor for the development of asthma later during childhood and adolescence ${ }^{10,11}$ and infants suffering from frequent and severe episodes of wheezing in the first year of life are at a higher risk of diminishing lung function, asthma and chronic obstructive pulmonary disease later in life. ${ }^{12-14}$ Hence, identifying risk/protective factors related to admissions in infants with recurrent asthma-like symptoms may help to develop early strategies for preventing admissions in this group of infants with recurrent asthma-like symptoms.

In older children and adults, asthma admissions' prevalence and related factors show significant variations among countries. ${ }^{15}$ However, specific information on the prevalence of admissions for wheezing exacerbation and associated factors in infants suffering from recurrent asthma-like symptoms, particularly from developing regions, is scarce.
This study aimed to determine the prevalence of admission for wheezing and associated factors in a sample of 2,079 infants with recurrent asthma-like symptoms from 11 centres in six South American countries.

\section{Methods}

This study is part of the International Study of Wheezing in Infants (EISL, from the Spanish "Estudio Internacional de Sibilancias en Lactantes") Phase 3 (South America), based on the general population, and designed to determine the prevalence of wheezing and associated risk/protective factors in random samples of infants during the first year of life. A detailed description of EISL methodology is published elsewhere. ${ }^{1}$ In short, EISL uses a validated questionnaire on wheezing and associated potential risk/protective factors ${ }^{16,17}$ to be completed by parents/guardians of children 12-15 months of age when attending their health care centres for official immunisation schedules or scheduled routine health care. It includes questions about wheezing episodes (onset, frequency and severity), protective/risk factors (pre-and postnatal tobacco exposure, breastfeeding, maternal education), day-care attendance, comorbidities such as pneumonia, and admissions for wheezing, visits to ED, severe wheezing episodes, among others. This study has been carried out in 11 centres from six South-American countries: Argentina (Buenos Aires), Brazil (Curitiba, Cuiabá, São Carlos, São José do Rio Preto, São Paulo and Uruguaiana), Colombia (Bucaramanga), Chile (Santiago), Peru (Lima) and Uruguay (Montevideo). For the EISL-3 
study, random samples of at least 735 infants, enough to detect a significant difference in the prevalence of recurrent wheezing (three or more episodes) of $5 \%$ between two centres, one of which should have $20 \%$ prevalence, with a $\mathrm{Cl}$ of $95 \%$ and a power of $85 \%$, were required from the participating centres. Centres obtained ethics approval to the requirements of the country and funded their study; parents or guardians who accepted to participate in the study filled in the questionnaire after reading and signing a full-informed written consent.

\section{Definitions}

The questions employed for assessing the severity of wheezing episodes in the past 12 months were: "Has your baby ever been hospitalised for wheezing?"; “In the past 12 months, has the wheezing or whistling in his/her chest ever been so severe (so intense) that you have had to take him/her to an ED (Hospital, Clinic, etc.)?"; and "Has the wheezing or the whistling in his/her chest been so severe that your baby was choking and having real difficulty breathing?". We also computed questions on potential risk/ protective factors for admissions in this group of infants as smoking during pregnancy, current maternal smoking, daycare attendance, exclusive breastfeeding during 4 months or more, number of siblings, maternal level of education, employment status of the mother, monthly household income, wheezing episode in the first 3 months of life, parental asthma, dermatitis during the first year of life, among others.

\section{Data analysis}

Descriptive statistics were employed to compare the prevalence of admission for wheezing in infants from different participating centres. We used multivariate logistic regression adjusted for centre, sex and birth weight to assess the factors associated with hospital admission for wheezing (risk/protection). The results are expressed as mean and $95 \% \mathrm{Cl}$, except for age (mean $\pm \mathrm{SD})$. A p-value less than 0.05 was considered statistically significant. Analysis was performed using statistical software (MedCalc Statistical Software version 19.5.3, Ostend, Belgium)

\section{Results}

A total of 11 centres provided 12,405 questionnaires correctly completed, and the mean response rate was $82.1 \%$; the mean age for the whole sample of infants $(50.6 \%$ male) was $13.4 \pm 1.5$ months. There were 2,079 infants with recurrent asthma-like symptoms, with a mean period of $13.3 \pm 1.3$ months; this section presents their hospital admission data for wheezing and associated factors. The prevalence of hospital admissions for wheezing in infants with asthma-like symptoms at the different participating centres is in Table 1; the mean prevalence of admission was 29.8\% (95\% Cl: 27.8-31.7), varying from $11.9 \%$ in Curitiba to $47.9 \%$ in Buenos Aires $(p<0.001)$. As an illustration, this was 3.3 times higher than the prevalence of admissions for asthma-like symptoms found in the whole sample $(9.0 \%$; 95\% Cl: 8.5-9.5), $\mathrm{p}<0.001$, which varied from $3.8 \%$ in Cuiaba to $22.1 \%$ in Buenos Aires.

Admission for wheezing was significantly associated with physician diagnostic of pneumonia, and $57.9 \%$ of infants with recurrent asthma-like symptoms admitted for wheezing have had the diagnosis pneumonia (OR: 5.34, 95\% $\mathrm{Cl}$ : 4.37-6.58, $\mathrm{p}=0.001)$. In infants visiting ED for wheezing, $37.9 \%$ reported admission for wheezing and both were significantly related (OR: 7.36; 95\% Cl: 5.28-10.17, $\mathrm{p}=0.0001$ ). Table 2 displays the correlations between hospitalisation for asthma-like symptoms and the other studied factors. The result of the adjusted multivariate logistic regression analysis is in Table 3, which shows the association between admission for recurrent asthma-like symptoms and computed risk/protective factors. Although a household income of $\geq$ USD 3,000 per month protected against admissions for wheezing, it is worth noting that the monthly household income varied significantly among centres $(p=0.001)$. On average, 68\% (95\% Cl: 65.88-70.01) reported a household income per month of $\leq$ USD 1,000, whereas $4.5 \%(95 \% \mathrm{Cl} 3.71-5.56)$ reported $\geq$ USD 3,000. The ORs and $95 \% \mathrm{Cl}$ for variables either significantly associated with or

Table 1 Prevalence of admissions for wheezing in 11 South American centres in infants with recurrent asthma-like symptoms. EISL Phase III-South America.

\begin{tabular}{lrcr}
\hline Centres & $\mathrm{N}$ & Admission for wheezing (\%) $(95 \% \mathrm{Cl})$ & Total with asthma-like symptoms \\
\hline Buenos Aires (Argentina) & 134 & $47.86(42.07-53.70)$ & 280 \\
Cuiabá (Brazil) & 25 & $18.9(13.17-26.47)$ & 132 \\
Curitiba (Brazil) & 23 & $11.92(8.07-17.25)$ & 193 \\
São Carlos (Brazil) & 21 & $29.58(20.23-41.02)$ & 71 \\
São José do Rio Preto (Brazil) & 67 & $19.48(15.64-23.99)$ & 344 \\
São Paulo (Brazil) & 119 & $41.18(35.65-46.93)$ & 289 \\
Uruguaiana (Brazil) & 48 & $32.43(25.42-40.34)$ & 148 \\
Santiago (Chile) & 35 & $19.23(14.16-25.57)$ & 182 \\
Bucaramanga (Colombia) & 28 & $35.00(25.45-45.92)$ & 80 \\
Lima (Peru) & 33 & $20.75(15.18-27.71)$ & 159 \\
Montevideo (Uruguay) & 84 & $41.79(35.19-48.70)$ & 201 \\
Total & 617 & $29.68(27.75-31.68)$ & 2,079 \\
\hline
\end{tabular}


Table 2 Correlation between admission for wheezing in infants with recurrent asthma-like symptoms and other study variables.

\begin{tabular}{|c|c|c|}
\hline & $\begin{array}{c}\text { Correlation } \\
\text { coefficient } \\
\text { (Rho) }\end{array}$ & p (2-tailed) \\
\hline Gender (male) & 0.051 & 0.021 \\
\hline Birth weight $\leq 2,500$ & 0.05 & 0.83 \\
\hline History of parental asthma & 0.077 & 0.001 \\
\hline History of parental eczema & 0.028 & 0.21 \\
\hline History of parental rhinitis & 0.016 & 0.51 \\
\hline Infant eczema & 0.006 & 0.77 \\
\hline Caesarean section birth & 0.003 & 0.90 \\
\hline Wheezing $\geq 7$ episodes & 0.109 & 0.001 \\
\hline $\begin{array}{l}\text { Wheezing in the first } 3 \text { months } \\
\text { of life }\end{array}$ & 0.13 & 0.001 \\
\hline $\begin{array}{l}\text { Physician diagnostic of } \\
\text { pneumonia }\end{array}$ & 0.368 & 0.001 \\
\hline Admission for pneumonia & 0.507 & 0.001 \\
\hline Colds $\geq 6$ or more a year & 0.087 & 0.001 \\
\hline Cold in the first 3 months of life & 0.044 & 0.052 \\
\hline Use of antibiotics $>4$ times a year & 0.006 & 0.81 \\
\hline Use of inhaled bronchodilators & 0.123 & 0.001 \\
\hline Use of inhaled corticosteroids & 0.206 & 0.001 \\
\hline Use of oral corticosteroids & 0.258 & 0.001 \\
\hline Passive tobacco exposure & 0.044 & 0.045 \\
\hline Maternal tobacco smoking & 0.107 & 0.001 \\
\hline $\begin{array}{l}\text { Tobacco smoking during } \\
\text { pregnancy }\end{array}$ & 0.093 & 0.001 \\
\hline Outdoor air pollution (smog) & 0.004 & 0.84 \\
\hline Dog in the house at birth & 0.051 & 0.027 \\
\hline Cat in the house at birth & 0.017 & 0.45 \\
\hline $\begin{array}{l}\text { Cat in the house during the first } \\
\text { year of life }\end{array}$ & 0.04 & 0.09 \\
\hline $\begin{array}{l}\text { Dog in the house during the first } \\
\text { year of life }\end{array}$ & 0.009 & 0.70 \\
\hline Molds stains on walls & 0.026 & 0.24 \\
\hline People living in the house $\geq 6$ & 0.015 & 0.50 \\
\hline Day-care attendance & 0.084 & 0.001 \\
\hline Breast feeding $\geq 4$ months & 0.089 & 0.001 \\
\hline $\begin{array}{l}\text { Maternal education low } \\
\text { ( } \leq 6 \text { years })\end{array}$ & 0.03 & 0.17 \\
\hline $\begin{array}{l}\text { Maternal education medium } \\
\text { (12 years) }\end{array}$ & 0.072 & 0.001 \\
\hline $\begin{array}{l}\text { Maternal education high } \\
\qquad(>12 \text { years })\end{array}$ & 0.093 & 0.001 \\
\hline $\begin{array}{l}\text { Household income per month } \\
\leq \mathrm{US} \$ 1,000\end{array}$ & 0.076 & 0.001 \\
\hline
\end{tabular}

not associated with admission for wheezing in infants with recurrent asthma-like symptoms are shown in Figure 1.

\section{Discussion}

The present study shows that about 30\% (rounded from 29.7\%) of infants with recurrent asthma-like symptoms
Table 3 Admission for wheezing and its relationship with other variables in infants with recurrent asthma-like symptoms. EISL Phase III South America (*).

\begin{tabular}{|c|c|c|c|}
\hline & OR & $95 \% \mathrm{Cl}$ & $\mathrm{p}$ \\
\hline Gender & 1.04 & $0.81-1.33$ & 0.753 \\
\hline Wheezing in the first 3 months & 1.30 & $1.02-1.66$ & 0.038 \\
\hline Use of inhaled corticosteroids & 1.78 & $1.38-2.29$ & 0.000 \\
\hline Severe episode of wheezing & 3.89 & $2.93-5.18$ & 0.000 \\
\hline Physician diagnosed asthma & 1.79 & $1.33-2.41$ & 0.000 \\
\hline Tobacco during pregnancy & 1.69 & $1.19-2.39$ & 0.003 \\
\hline $\begin{array}{l}\text { Second-hand tobacco exposure } \\
\text { (passive) }\end{array}$ & 1.00 & $0.77-1.29$ & 0.969 \\
\hline Parental asthma & 1.19 & $0.88-1.60$ & 0.252 \\
\hline Day-care attendance & 0.91 & $0.68-1.20$ & 0.493 \\
\hline $\begin{array}{l}\text { Maternal high educational level } \\
\quad(>12 \text { years) }\end{array}$ & 0.66 & $0.51-0.85$ & 0.001 \\
\hline Cold in the first 3 months of life & 1.32 & $1.03-1.70$ & 0.027 \\
\hline Infant eczema & 0.91 & $0.71-1.17$ & 0.479 \\
\hline Siblings $\geq 2$ & 1.03 & $0.79-1.35$ & 0.813 \\
\hline Breastfeeding for $\geq 4$ months & 0.72 & $0.54-0.96$ & 0.004 \\
\hline $\begin{array}{l}\text { Monthly household income } \\
\leq \text { US\$ } 1.000\end{array}$ & 0.80 & $0.60-1.05$ & 0.107 \\
\hline Use of oral corticosteroids & 2.16 & $1.65-2.83$ & 0.000 \\
\hline $\begin{array}{l}\text { Monthly household income } \\
\geq \text { US\$ } 3,000\end{array}$ & 0.34 & $0.18-0.67$ & 0.002 \\
\hline
\end{tabular}

*Adjusted by sex, birth weight, and centre.

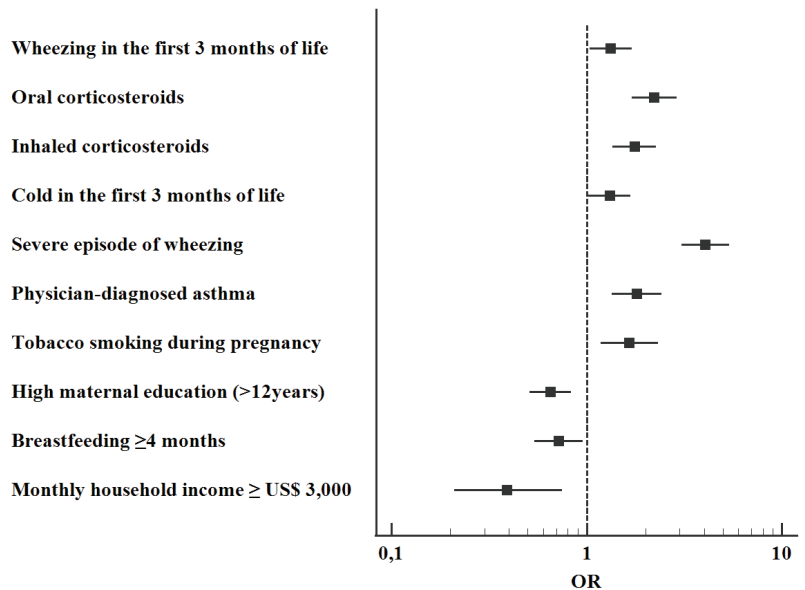

Figure 1 Risk/protective factors significantly associated with admission to hospital in infants with recurrent asthmalike symptoms. EISL Phase 3-South America.

were admitted to hospital by wheezing exacerbations and it was mainly associated with a more severe progression evidenced by the use of oral and inhaled corticosteroids, visits to ED and severe episodes of wheezing. In older asthmatic children and adolescents, a more severe progression characterised by previous admissions, asthma-related ED visit, poor control of asthma symptoms, tobacco exposure, having a lower household income, use of corticosteroids, being preschool-aged, among others, are significant risks for asthma admissions and re-admissions..$^{18,19}$ In our group 
of infants with recurrent asthma-like symptoms, those with early onset of wheezing and maternal smoking during pregnancy were at considerably higher risk of admission for wheezing.

The association between severity of wheezing illness, higher prevalence of visiting ED, and admissions has been found in developing and full-resourced countries, ${ }^{1-3}$ but with higher rates in less-resourced countries. ${ }^{1,7}$ Nevertheless, longitudinal studies in affluent countries show that $16 \%$ of infants required admission due to severe wheezing. ${ }^{4}$ In a different study design that analysed a large sample of infants and toddlers with asthma-like symptoms, the authors found high rates of health care use and admissions for wheezing in this group of patients. ${ }^{2}$ The authors identified a strong association between the severity of recurrent asthma-like symptoms and admission to hospital for wheezing, suggesting the need to improve the symptoms' severity recognition and medical management because this might prevent visits to ED and admissions in this group of infants, particularly in developing countries..$^{3,4,6,19-24}$ In infants with troublesome recurrent asthma-like symptoms and older asthmatic children, there are several treatment-related issues: repeated use of antibiotics, poor inhalation technique and treatment adherence, ICS at low doses, discontinuous use of ICS, among others, will predictably result in poor treatment outcomes. ${ }^{2-4,7,20-22,25-27}$ In this study, $41.5 \%$ of infants with recurrent asthma-like symptoms whose parents also reported severe episode and visit ED have not received ICS; similar percentages have been found in previous studies. ${ }^{21,22,27}$ According to major guidelines, ICS therapy in preschool children with high risk for asthma is an effective approach for preventing exacerbations and symptom reduction. ${ }^{27}$ Recently, in a large sample of infants with asthma-like symptoms, there was a significant reduction in the rate of admission for wheezing after starting with controller therapy. ${ }^{2}$ In infants with recurrent asthma-like symptoms, using low doses of ICS would have an unclear effect on avoiding oral corticosteroid prescription or preventing admissions ${ }^{28}$; however, using high doses of inhaled budesonide decreased admissions for wheezing exacerbations in preschool children. ${ }^{29} \mathrm{~A}$ nationwide study in Brazil has recently shown that government ICS provision without charge for parents or patients is associated with decreased hospital admission for asthma in children and adults. ${ }^{30} \mathrm{~A}$ study on the time trend of prevalence of recurrent asthma-like symptoms in infants from South America ${ }^{25}$ showed that the prevalence of admission for wheezing remained high in 7 years even when ICS were also provided without cost. However, in those infants, ICS were prescribed in less than $16 \%$ of them, which agrees with other studies showing that only a minority of eligible children received controller medications. ${ }^{2,3,20}$ Furthermore, in a nationwide study performed in an affluent country, $68.7 \%$ of infants with recurrent asthma-like symptoms received ICS, but only 1.8 unit was dispensed over 6 months, suggesting discontinuous use for different reasons. ${ }^{20}$

Our results show wide variability in the prevalence of admission for asthma-like symptoms among participating centres, with about a four-fold difference between the centre with the lowest and highest prevalence. This finding is within the context of the vast international variability in the prevalence, severity and risk of asthma symptoms in infants, children and adolescents as found in large epidemiological studies.1,15 The authors have no explanation for the variability in admissions for wheezing found in our infants; however, it is likely related to multiple factors as local medical practice and treatment preferences, proper inhalation techniques, access to effective controller medications, environmental exposures, socioeconomic status, parental health education, health personnel awareness on severe progression, management of severe wheeze infants at the ED, among others.

Most of the risk/protective factors associated with admissions in infants with recurrent asthma-like symptoms are similar to those reported for infants suffering from the condition with or without the antecedent of hospital admissions. ${ }^{1,5,9}$ Reported common upper airway infection (common cold) in the first 3 months of life was related to a higher admission rate in the studied infants supporting the crucial role of acute viral infections (common colds) as the main triggers of asthma symptoms exacerbation in individuals at all ages, and related to the development of asthma later in life. ${ }^{10-13}$ Avoiding viral infections in the first 3 months of life may likely have critical preventive implications, as found in a recent study on the factors that may modify the time to the first wheezing episode. ${ }^{31}$ Probably, extending postnatal maternity leave and delaying day-care entry for the second semester of life could help to decrease admissions for asthma-like symptoms in infants. Furthermore, this may be beneficial for extending breastfeeding for at least the first 4 months, a significant protective factor for wheezing and colds in the first 3 months of life.

Smoking during pregnancy was a predictor for a higher rate of admissions for wheezing in our group of infants with recurrent asthma-like symptoms. The current evidence shows that exposure to tobacco smoke during pregnancy and postnatal (maternal smoking) is associated with a more severe progression of recurrent asthma symptoms, comorbidities like pneumonia, ED visits, and subsequent admissions. ${ }^{21,24,31}$ Furthermore, it is also associated with the development of asthma and diminish lung function in adolescents and young adults. ${ }^{32-34}$ The international prevalence of tobacco smoking during pregnancy is still high and seems to be independent of the country's socioeconomic status ${ }^{1,7}$; in the present study, on average, $14 \%$ of mothers reported smoking during pregnancy.

Low socioeconomic condition of life is another factor frequently associated with a higher prevalence and severity of asthma at any age. ${ }^{35}$ This study shows that a low socioeconomic status (at the individual level) is associated with a higher prevalence of admissions for wheezing in infants with asthma-like symptoms, ${ }^{7}$ which is higher in the non-affluent countries. ${ }^{1}$ Low socioeconomic status is a significant predictor of subsequent ED, hospital admissions and readmissions for acute asthma in older children. ${ }^{19,36,37}$ Maternal education of more than 12 years was protective against admissions in infants with recurrent asthma-like symptoms, which agrees with other studies in older children, showing that higher parental education is related to better asthma control. ${ }^{38}$ It is worth mentioning that although we found the highest income (household income of $\geq$ US\$ 3,000 per month) was a significant protective factor for admissions, it would be misleading because it represented just the $4.5 \%$ of infants with asthma-like symptoms studied. 
Breastfeeding for at least 4 months protected against admission in this group of infants with recurrent asthma-like symptoms, which agrees with other studies reporting a significant effect of prolonged breastfeeding on decreasing the risk for wheezing during the first early infancy. ${ }^{39}$ Still, this protective effect would decline over time, ${ }^{40}$ and it is not present when supplementing breastfeeding with formula. ${ }^{41}$

Limitations and strength. In addition to the inherent limitations of all cross-sectional studies, mainly on concluding causality, the present study in infants with recurrent asthma-like symptoms has the potential limitation of using a parental report on asthma-like symptoms instead of a physician report. Nevertheless, evidence validates the parental report of wheezing versus clinical examination in infants attending ED with acute wheezing episodes. ${ }^{16,17}$ Besides, the admission for infant wheezing exacerbation is difficult for parents to forget; thus, parental recall bias is improbable.

The strengths of the present study include its population-based sampling strategy, large sample size and high response rate. Besides, it adds further information on admission to hospital and related factors in infants with asthma-like symptoms at an international level. It is worth noting that associated risk/protective factors found in this group of infants with recurrent asthma-like symptoms closely resemble the risk for admissions found in older asthmatic children and adolescents. The present study provides missing international multicentre information focused on risk/protective factors for asthma-symptoms admission in infants from low-medium income countries. These data could help in developing strategies oriented to prevent hospital admissions of infants with asthma symptoms. In that direction, improving the management of infants with recurrent asthma-like symptoms at primary care to reduce exacerbations and severity of wheezing would be one of the most realistic approaches.

Hospital admission is not just highly traumatic for parents and infants but severely affects the family's quality of life, with all the inherent psychosocial distress and implications. As in older asthmatic children and adults, it also reflects the possible failure to prevent the event. Many of these young children had had several episodes of recurrent wheezing and repeated consultations for wheezing, which should be considered as an alarm signal to improve interventions if we want to avoid exacerbations and subsequent hospitalisations in this group of infants. ${ }^{2-4,7,20-24,27}$

\section{Conclusions}

The prevalence of admission for wheezing in infants with asthma-like symptoms was very high, as described in other studies in affluent and non-affluent countries. It varies widely among countries and it is related to well-known asthma risk/protective factors as early onset of wheezing, the severity of progression, poor symptoms control, tobacco smoking in pregnancy and low socioeconomic status. Breastfeeding for 4 months and high maternal education were strong protectors against admissions in this group of infants with recurrent asthma-like symptoms.

\section{Funding}

This research did not receive any specific grant from funding agencies in the public, commercial, or not-for-profit sectors

\section{Declarations of interest}

The authors declare no conflicts of interest.

\section{Authorship/Author contributions}

All authors (EISL Phase 3 South American Group) have made substantial contributions to the conception and design of the study, acquisition, analysis, and interpretation of data; drafting the article or revising it critically for important intellectual content and final approval of the version to be submitted. The authors alone are responsible for the content and writing of the article.

\section{Acknowledgments}

The authors thank all the parents who participated in the study and the health personnel from the participant Primary Health Care centres at each country for their valuable collaboration.

\section{EISL Phase III South American Group}

Gabriela A. Szulman, Ilse Behrends, Ángela Spagnuolo de Gentile (Buenos Aires, Argentina); Dirceu Solé, Carolina Aranda, Caroline Della Bianca, Gustavo F. Wandalsen (São Paulo, Brazil); Nelson Rosario, Herberto Chong (Curitiba, Brazil); Eliana C. Toledo, Cibele Matsuura de Oliveira (São José do Rio Preto, Brazil; Líllian Sanchez-Lacerda Moraes, Olga Akiko Takano (Cuiabá, Brazil); Marilyn Urrutia-Pereira, Juan Carlos Ivancevich (Uruguaiana, Brazil); Patrícia Polles de Oliveira Jorge (São Carlos, Brazil); Javier Mallol ${ }^{\dagger}$, Viviana Aguirre (Santiago, Chile); Jurg Niederbacher-Velásquez, Carlos A. Cuadros-Mendoza, Diana C. Archila-Santamaria, Leonela Ballesteros-Chaparro, Juan M. Joya-Moreno, (Bucaramanga, Colombia); Erika Arruda-Chaves, Silvia Cachay-Chávez, Claudia Mory-Arciniega (Lima, Perú); Catalina Pinchak, Anabel Akiki, Silvia Brea, Maria Nelly Márquez, Isabel Moreira, Adriana Muiño, Marilyn Valentin (Montevideo, Uruguay); Luis-García Marcos, Virginia PérezFernández, and Antonela Martínez-Torres (Murcia, Spain).

\section{Ethical disclosures: Protection of human subjects and animals in research}

The authors declare that the procedures followed were in accordance with the regulations of the responsible Clinical Research Ethics Committee and in accordance with those of the World Medical Association and the Helsinki Declaration.

${ }^{\dagger}$ Coordinator EISL3 South America 


\section{Confidentiality of data}

The authors declare that no patient data appear in this article.

\section{Right to privacy and informed consent}

The authors declare that no patient data appear in this article.

\section{References}

1. Mallol J, García-Marcos L, Solé D, Brand P, EISL Study Group. International prevalence of recurrent wheezing during the first year of life: variability, treatment patterns and use of health resources. Thorax. 2010;65:1004-9. https://doi. org $/ 10.1136 /$ thx.2009.115188

2. Levine $H$, Leventer-Roberts $M$, Hoshen M, Mei-Zahav $M$, Balicer R, Blau H. Healthcare utilisation in infants and toddlers with asthma-like symptoms. Pediatr Pulmonol. 2019;54:156777. https://doi.org/10.1002/ppul.24429

3. Bisgaard $\mathrm{H}$, Szefler $\mathrm{S}$. Prevalence of asthma-like symptoms in young children. Pediatr Pulmonol. 2007;42:723-8. https://doi. org/10.1002/ppul.20644

4. Herr M, Nikasinovic L, Foucault C, Le Marec AM, Giordanella JP, Just $\mathrm{J}$, et al. Management of wheezing disorders in infants participating in the PARIS birth cohort. Rev Mal Respir. 2012;29:52-9. https://doi.org/10.1016/j.rmr.2011.05.016

5. Garcia-Marcos L, Mallol J, Solé D, Brand PL, Martinez-Torres A, Sanchez-Sols $M$, et al. Pneumonia and wheezing in the first year: an international perspective. Pediatr Pulmonol. 2015;50:1277-85. https://doi.org/10.1002/ppul.23160

6. Kuehni CE, Strippoli MP, Low N, Brooke AM, Silverman M. Wheeze and asthma prevalence and related health-service use in white and south Asian pre-schoolchildren in the United Kingdom. Clin Exp Allergy. 2007;37:1738-46. https://doi. org/10.1111/j.1365-2222.2007.02784.x

7. Mallol J, Solé D, Garcia-Marcos L, Rosario N, Aguirre V, Chong $\mathrm{H}$, et al. Prevalence, severity, and treatment of recurrent wheezing during the first year of life: a crosssectional study of 12,405 Latin American infants. Allergy Asthma Immunol Res. 2016;8:22-31. https://doi.org/10.4168/ aair.2016.8.1.22

8. Klinnert MD, Price MR, Liu AH, Robinson JL. Morbidity patterns among low-income wheezing infants. Pediatrics. 2003;112:4957. https://doi.org/10.1542/peds.112.1.49

9. Bueso A, Figueroa M, Cousin L, Hoyos W, Martínez-Torres AE, Mallol J, et al. Poverty-associated risk factors for wheezing in the first year of life in Honduras and El Salvador. Allergol Immunopathol (Madr). 2010;38:203-12. https://doi. org/10.1016/j.aller.2010.01.003

10. Kappelle L, Brand PL. Severe episodic viral wheeze in preschool children: high risk of asthma at age 5-10 years. Eur J Pediatr. 2012;171:947-54. https://doi.org/10.1007/s00431-011-1663-7

11. Hallas HW, Chawes BL, Rasmussen MA, Arianto L, Stokholm J, Bønnelykke K, et al. Airway obstruction and bronchial reactivity from age 1 month until 13 years in children with asthma: a prospective birth cohort study. PLoS Med. 2019;16:e1002722. https://doi.org/10.1371/journal.pmed.1002722

12. Postma DS, Bush A, van den Berge M. Risk factors and early origins of chronic obstructive pulmonary disease. Lancet. 2015;385:899909. https://doi.org/10.1016/S0140-6736(14)60446-3

13. Martínez FD. The origins of asthma and chronic obstructive pulmonary disease in early life. Proc Am Thorac Soc. 2009;6:272-7. https://doi.org/10.1513/pats.200808-092RM
14. Ma H, Li Y, Tang L, Peng $X$, Jiang $L$, Wan J, et al. Impact of childhood wheezing on lung function in adulthood: a meta-analysis. PLoS One. 2018;13(2):e0192390. https://doi. org/10.1371/journal.pone. 0192390

15. Global Asthma Report 2018. Hospital admissions for asthma. http://www.globalasthmareport.org/burden/admissions.php (accessed November 2020).

16. Bianca AC, Wandalsen GF, Miyagi K, Camargo L, Cezarin D, Mallol J, et al. International Study of Wheezing in Infants (EISL): validation of written questionnaire for children aged below 3 years. J Investig Allergol Clin Immunol. 2009;19:35-42.

17. Chong Neto HJ, Rosario N, Dela Bianca AC, Sole D, Mallol J. Validation of a questionnaire for epidemiologic studies of wheezing in infants. Pediatr Allergy Immunol. 2007;18:86-7. https://doi.org/10.1111/j.1399-3038.2006.00488.x

18. Jroundi I, Tse SM. Long-term asthma-related readmissions: comparison between children admitted and not admitted to the intensive care unit for critical asthma. J Asthma. 2019;20:1-9. https://doi.org/10.1080/02770903.2019.1663430

19. Ardura-Garcia C, Stolbrink M, Zaidi S, Cooper PJ, Blakey JD. Predictors of repeated acute hospital attendance for asthma in children: a systematic review and meta-analysis. Pediatr Pulmonol. 2018;53:1179-92. https://doi.org/10.1002/ppul.24068

20. Belhassen M, De Blic J, Laforest L, Laigle V, Chanut-Vogel C, Lamezec L, et al. Recurrent wheezing in infants: a population-based study. Medicine (Baltimore). 2016;95(15):e3404. https://doi.org/10.1097/MD.0000000000003404

21. Reindal L, Øymar K. Hospital admissions for wheezing and asthma in childhood - are they avoidable? J Asthma. 2006;43:801-6. https://doi.org/10.1080/02770900601034320

22. Østergaard MS, Kjærgaard J, Kristensen MM, Reventlow S, Poulsen A, Isaeva E, et al. Recurrent lower respiratory illnesses among young children in rural Kyrgyzstan: overuse of antibiotics and possible under-diagnosis of asthma. A qualitative FRESH AIR study. NPJ Prim Care Respir Med. 2018;28:13. https://doi.org/10.1038/s41533-018-0081-y

23. Skirrow H, Wincott T, Cecil E, Bottle A, Costelloe C, Saxena S. Preschool respiratory hospital admissions following infant bronchiolitis: a birth cohort study. Arch Dis Child. 2019;104:658-63. https://doi.org/10.1136/archdischild-2018-316317

24. Alvim CG, Nunes S, Fernandes S, Camargos P, Fontes MJ. Oral and inhaled corticoid treatment for wheezing in the first year of life. J Pediatr (Rio J). 2011;87:314-18. https://doi. org/10.2223/JPED.2101

25. Mallol J, Solé D, Aguirre V, Chong H, Rosario N, GarciaMarcos L, et al. Changes in the prevalence and severity of recurrent wheezing in infants: the results of two surveys administered 7 years apart. J Asthma. 2018;55:121422. https://doi.org/10.1080/02770903.2017.1403625

26. Klok T, Kaptein AA, Duiverman EJ, Brand PL. It's the adherence, stupid (that determines asthma control in preschool children)! Eur Respir J. 2014;43:783-91. https://doi. org/10.1183/09031936.00054613

27. Beigelman A, Bacharier LB. Management of preschool children with recurrent wheezing: lessons from the NHLBI's asthma research networks. J Allergy Clin Immunol Pract. 2016;4:1-8; quiz 9-10. https://doi.org/10.1016/j.jaip.2015.10.003

28. McKean M, Ducharme F. Inhaled steroids for episodic viral wheeze of childhood. Cochrane Database Syst Rev. 2000;(2):CD001107. https://doi.org/10.1002/14651858.CD001107

29. Razi CH, Cörüt N, Andıran N. Budesonide reduces hospital admission rates in preschool children with acute wheezing. Pediatr Pulmonol. 2017;52:720-8. https://doi.org/10.1002/ ppul.23667

30. Bezerra de Menezes M, Ponte EV, Bertagni Mingotti CF, Carvalho Pinto RM, Bagatin E, Bião Lima V, et al. Provision of inhaled corticosteroids is associated with decrease in hospital admissions in Brazil: a longitudinal nationwide study. 
Respir Med. 2020;166:105950. https://doi.org/10.1016/j. rmed.2020.105950

31. Pacheco-Gonzalez RM, Mallol J, Solé D, Brand PL, PerezFernandez V, Sanchez-Solis M, et al. Factors associated with the time to the first wheezing episode in infants: a crosssectional study from the International Study of Wheezing in Infants (EISL). NPJ Prim Care Respir Med. 2016;26:15077. https://doi.org/10.1038/npjpcrm.2015.77

32. Narvestad H, Vestergaard CH, Rytter D, Bech BH. Maternal smoking during pregnancy and offspring utilisation of health care services: a population-based cohort study. Paediatr Perinat Epidemiol. 2019;33:384-93. https://doi.org/10.1111/ ppe.12577

33. Lawder R, Whyte B, Wood R, Fischbacher C, Tappin DM. Impact of maternal smoking on early childhood health: a retrospective cohort linked dataset analysis of 697003 children born in Scotland 1997-2009. BMJ Open. 2019;9(3):e023213. https://doi.org/10.1136/bmjopen-2018-023213

34. Thacher JD, Gehring U, Gruzieva O, Standl M, Pershagen G, Bauer CP, et al. Maternal smoking during pregnancy and early childhood and development of asthma and rhinoconjunctivitis - a MeDALL project. Environ Health Perspect. 2018;126(4):047005. https://doi.org/doi-10.1289/EHP2738

35. Uphoff E, Cabieses B, Pinart M, Valdés $M$, Antó JM, Wright J. A systematic review of socioeconomic position in relation to asthma and allergic diseases. Eur Respir J. 2015;46:364-74. https://doi.org/10.1183/09031936.00114514
36. Owens L, Laing IA, Zhang G, Turner S, Le Souëf PN. Airway function in infancy is linked to airflow measurements and respiratory symptoms from childhood into adulthood. Pediatr Pulmonol. 2018;53:1082-8. https://doi.org/10.1002/ ppul.24062

37. Sakai-Bizmark R, Chang RR, Mena LA, Webber EJ, Marr EH, Kwong KY. Asthma hospitalizations among homeless children in New York state. Pediatrics. 2019;144:e20182769. https:// doi.org/10.1542/peds.2018-2769

38. Strömberg Celind F, Wennergren G, Vasileiadou S, Alm B, Åberg N, Goksör E. Higher parental education was associated with better asthma control. Acta Paediatr. 2019;108:920-6. https://doi.org/10.1111/apa.14610

39. Garcia-Marcos L, Mallol J, Solé D, Brand PL, EISL Study Group. International study of wheezing in infants: risk factors in affluent and non-affluent countries during the first year of life. Pediatr Allergy Immunol. 2010;21:878-88. https://doi. org/10.1111/j.1399-3038.2010.01035.x

40. Quigley MA, Carson C, Kelly Y. Breastfeeding and childhood wheeze: age-specific analyses and longitudinal wheezing phenotypes as complementary approaches to the analysis of cohort data. Am J Epidemiol. 2018;187:1651-61. https://doi. org/10.1093/aje/kwy057

41. Azad MB, Vehling $L$, Lu Z, Dai D, Subbarao P, Becker $A B$, et al. Breastfeeding, maternal asthma and wheezing in the first year of life: a longitudinal birth cohort study. Eur Respir J. 2017;49:1602019. https://doi.org/10.1183/13993003.02019-2016. 